\title{
American Domination of the Net: A Preliminary Ethnographic Exploration of Causes, Economic Implications for Europe, and Future Prospects
}

\author{
Eric K. Clemons \\ The Wharton School \\ clemons@upenn.edu
}

\author{
Helmut Krcmar \\ Technical University of \\ Munich \\ krcmar@in.tum.de
}

\author{
Sebastian Hermes \\ Technical University of \\ Munich \\ Sebastian.Hermes@in.tum.de
}

\author{
Jeena Choi \\ The Wharton School \\ jbrenda1989@gmail.com
}

\begin{abstract}
European executives largely agree that American operators of online platforms dominate online business in the EU. There is less consensus on the reasons for American domination and on the possible economic consequences of this domination for the growth of $E U$ business, for employment, for the strength of the EU economies, or for the national security of individual EU member states. With a series of interviews with German executives in a range of industries we examine opinions of the causes of American domination of the net, the current consequences, and the potential for future economic harm. We develop a set of hypotheses, which can be examined with a larger survey and with econometric analysis.
\end{abstract}

\section{Introduction}

European online infrastructure is largely controlled by a small number of American giants, which operate large networks and consumer-focused extensible platforms. Google's Android platform dominates mobile computing. Amazon does not yet dominate all shopping, but it has the dominant online shopping platform and is extending this platform to offer convenient smart home management, including voice-based shopping. Facebook is the dominant social networking platform, and indeed in much of the world it is the only social networking platform of any significance. And the market for cloud services is shared among American giants Microsoft, Google, Amazon, and Salesforce. Microsoft also continues to dominate the traditional desk-top platform, though it has not been able to dominate any aspect of online infrastructure and is not a factor outside of cloud services.

Does this matter? Is this American domination of platform-based consumer-focused infrastructure important? It clearly appears significant to the European Commission, which has recently imposed a third fine on Google for abuse of monopoly power with its Android platform [28].

How would we as academic researchers in information systems economics and strategy assess the significance of American domination of consumer-focused platform-based web services? Does it affect economic growth in the EU? Does it affect EU employment? Does it affect national security? Why did it happen? And, if indeed it does matter, what are the URI: https://hdl.handle.net/10125/60047

ISBN: 978-0-9981331-2-6

(CC BY-NC-ND 4.0) appropriate responses? What, if anything, should be done?

Our research methodology for this paper reflects its position as the first, exploratory study in a larger multifaceted study that will entail hypothesis testing with surveys and econometric analysis. Our research methodology in this paper begins with ethnographic studies, a small set of in-depth semantically rich interviews intended to allow us to develop our hypotheses. This paper is part of an ongoing research effort. The limitations of this paper and of the first stage of our study are addressed in a section on limitations. The next steps required to complete our analyses are reviewed in a section on future research.

\section{Historical Context and Motivation}

In an uncertain world, some industries have always been considered essential to national security. In 1904 First Sea Lord Jackie Fisher was concerned that if another European War were to occur, Britain would desperately need battleships. Battleship turrets were the most complex machinery of the era. He knew that if he stopped Purchasing battleships in 1904, he might have no remaining source of turret technology outside of Germany. Although Fisher considered Germany an ally in any future European conflict, battleship technology was too critical to entrust to any ally, and Fisher made expensive and unpopular commitments to the defense industry to preserve the necessary capability within Britain [19]. One might argue that internet technology and platform technology are as important today as naval capability was before the First World War. If President Trump can argue that aluminum and steel are so critical to national defense that competing companies in Europe, China, and Canada cannot collectively be trusted to meet US national security requirements [31], then clearly Europe can argue that internet technology is essential today. Similarly, President Trump has argued that US jobs in coal, steel, and aluminum [9] are so essential to the US economy that they are worth protecting on national security grounds. Surely EU countries can argue that it is worth protecting at least some participation in the most profitable industries in today's economy.

We are not the first academic authors to address American domination of the net. A conference paper on the same themes was presented in Berlin in 2016 
[8]. But this paper is the first step we have seen towards an integrated academic study of the problem.

Likewise, we are not the only authors addressing how to proceed to mitigate the domination of the net by American platforms. A coalition of German industrial firms has been studying and writing about how to respond [32]. Their proposal is to form a cross-industry coalition with its own portal, so that German consumers could have a German identity. That is, German consumers could log into future consumer-focused websites using a German login, instead of using the Facebook or Google or Amazon logins. It is not yet clear how this would mitigate any of the risks of American domination. Individuals do not use Facebook or Google or Amazon solely so that they have an ID to $\log$ into other systems, and consumers will continue to use Google to search, Facebook to hang out with friends online, and Amazon to shop. This proposal does not address the domination of American platforms in those areas. Again, we believe that our paper is the first step towards an integrated academic study of the extent of the problem and the first attempt at developing a strategy for responding.

\section{Review of the Role of Semantically Rich Case Studies}

Perhaps the most important proponent of using ethnographic observation and semantically rich case studies for the generation of testable hypotheses is [13]. Moreover, others have explored the significance of such studies specifically in the field of information systems research; see, for example, [20] and [3].

We feel that the questions we are asking are important, but that we are not yet ready to conduct more formal research. Until we are certain we are asking the right questions and asking all of the right questions, it is premature to conduct large surveys to explore the answers to those questions. Until we know whether executives believe that economic harm has occurred, and until we know what factors executives believe are significant or what sectors have been affected, it may likewise be premature to begin our statistical analyses. [21] provides moral support for assessing importance before conducting our formal research.

In the development of any field or discipline, there comes a period where 'respectability' insidiously reigns. ... Subtly, choices are made which profoundly affect the field: methodological rigor and precision become prized over phenomenological significance, researching over scholarship, conceptual edifices for scientists only, and reification over elucidation. [21, p. 5]

We do expect to have statistical significance in the later elements of our study of American domination of the net in Europe. However, [22] reminds us that statistical significance alone is not sufficient. It does not provide an explanation of causal mechanisms, and thus does not provide corroboration of theories. Moreover, statistical significance alone does not provide guidance for strategic responses:

$[T]$ he finding of statistical significance is perhaps the least important attribute of a good experiment: it is never a sufficient condition for concluding that theory has been corroborated, [nor] that a useful empirical fact has been established with reasonable confidence. ... The value of any research can be determined, not from the statistical results, but only by skilled subjective evaluation of the coherence and reasonableness of the theory, the degree of experimental control employed, the sophistication of the measuring techniques, the scientific or practical importance of the phenomena studied, and so on. [22, p. 158159]

Even earlier, [18] defends the essential, indeed foundational role of subjective, qualitative data in tying together empirical research:

Qualitative data and analysis function as the glue that cements the interpretation of multimethod results. In one respect, qualitative data are used as the critical counter-point to quantitative methods. [18, p.609]

More recently, information systems researchers have published case studies that were used to develop theories, which we subsequently explored and tested by others. See for example, [6], who used the case study of Capital One to formulate the theory of newly vulnerable markets. The same authors then used a later, larger study of Capital One, after it had expanded into other lines of business, to test the theory [7]. Their use of Capital One was selected because it provided a natural experiment, consistent with the philosophy of [13] and [20] for using case studies. Subsequent studies by other authors have also used case studies in information systems to test the theory of newly vulnerable markets; see, for example [15].

\section{The Historical Role of Platforms and of Platform Envelopment}

The recent attention to the platform revolution [23] suggests that platform operators have gained power only recently, and that platform envelopment as a form of monopoly power may be quite recent. The most obvious example of a platform-based strategy and the ability to develop monopoly power is Google and the development of Android, described more fully below.

The most recent case resolved by litigation was the American Department of Justice complaint against Microsoft for bundling features like Internet Explorer into their Windows operating system, pre-installing Internet Explorer, and creating interoperability problems for Netscape.

But the problems proposed by extensible technology platforms and by the use of platform envelopment 
strategies to gain monopoly power have existed for decades. For example, AT\&T operated the first commercially successful radio station, WEAF, in New York in 1922. The Federal Radio Commission, the precursor to the Federal Communications Commission, was concerned that since AT\&T was the only operator of long distance telecommunications in the US, AT\&T could deny other operators of radio stations the technology they needed to create multi-station networks, by denying them the ability to transmit signals over land lines to remote locations for rebroadcast. The Commission therefore forced AT\&T to choose between operating a commercial radio station or operating its telephony business, effectively ending their platform envelopment strategy [34].

\section{Motivation and Propositions, Used to Generate Hypotheses}

Our initial expectations when starting this study were that American firms had earned billions of Euros monetizing private and personal information, in ways that were illegal for European firms. This gave American firms an incentive to enter markets that European firms did not have. Google's advertising business is its largest revenue source, and it is largely based on revenue streams from monetizing information based on individual customers' search history, email, GPS data, and numerous other sources. Facebook's largest revenue stream likewise comes from monetizing private information from its billions of users. Since there are no effective European competitors, these American giants enjoy near-monopoly power in the EU.

Additionally, we expected that American firms then used their core businesses to develop platform envelopment strategies [14, 23, 24], leveraging their near monopolies to dominate other business sectors. Google used revenue from paid search to develop Android. It used the Mobile Application Distribution Agreement (MADA) to control placement of applications on all Android devices $[11,12]$. The control created by the MADA gave Google the power to determine which apps could succeed, and which apps could not succeed in Europe. Indeed, abuse of the Android platform to obtain unfair (monopoly) advantage is the basis of the most recent 2018 EU Competition Commission's complaint against Google [29].

Google is not alone in leveraging power in one core area to develop a powerful platform with a platform envelopment strategy. Amazon has used its domination of online sales to develop massive control over online books, and Apple has used its domination of online music sales to support very aggressive pricing models in its negotiations with music publishers, though neither of these appear to approach full monopoly power.

The creation and defense of a sequence of monopolies clearly violated both European and American antitrust law, and was the basis of the Department of Justice's successful litigation against Microsoft in 1998
[4]. See complaint: [33]. And yet, the courts' understanding of monopoly power in a platform envelopment strategy is less mature and less complete than the understanding of monopoly power in more traditional settings, especially in manufacturing.

Thus, our expectation was that the revenue source created by monetizing private information, when skillfully combined with leveraging initial monopoly positions to develop subsequent platform-based monopolies, would be widely seen as the basis of American domination.

\section{Description of Recent Major Privacy Violations}

Table 1 (at end) lists 49 major incidents of privacy violations as reported in the global mass media. The incidents occurred over the past eight years, and they originated almost equally within the US and outside the US. The references to the source material used to create these tables will be available online as Appen$\operatorname{dix} \mathrm{A}$, which includes 52 articles obtained from published news reports.

As we expected, the bulk of the reported incidents were against American firms. The vast majority, 40 out of 49 incidents or $82 \%$, were against American firms. When formal complaints are examined the ratio is even more striking, with 25 out of 26 , or $96 \%$ of complaints filed against American firms. Additionally, further examination indicated that many of these privacy violations were of economic, competitive, and strategic importance to these American firms. Not surprisingly, we found that a slight majority, 17 of 28 or $61 \%$ of the formal complaints were filed in the EU. Again not surprisingly, we found that the EU, and Germany in particular, were more likely to impose some form of punishment, with 13 out of 22 or $59 \%$ of penalties imposed in the EU. Finally, and not surprisingly, the vast majority of penalties, 21 out of 22 or $95 \%$, were imposed against US firms.

Although we were able to substantiate empirically the role of monetizing privacy to create massive revenue streams that were not available to European firms, as described below our interviews did not show that executives shared our beliefs in the importance of either privacy violations or antimonopoly violations as the principal source of American companies' online power. It was necessary to develop a more comprehensive explanation for the domination of the net in the EU by a small number of American platform operators.

\section{Results of Our Interviews}

In June of 2018 we conducted 10 interviews with executives or officers in 8 organizations, including financial services, software services, manufacturers of consumer appliances, manufacturers of heavy industrial equipment, automobile manufacture, and the German military. All of these interviews were with German 
firms, which is a serious limitation that will be addressed in subsequent studies. While the EU is intended to function as a single market, it is not clear that all European executives face the same problems or have the same reactions to them.

Our interviews showed that our initial assumptions were far too simplistic, at least as an explanation of the beliefs of our German interview subjects. The results of our interviews are summarized below. We reported all of the answers suggested by our interview subjects; we list them by our subjective assessment of the strength of the subjects' beliefs and of the frequency with which individual ideas were suggested by different executives.

\subsection{Why do American firms dominate the net in Europe?}

American firms faced a single market with a single regulatory regime while European firms faced fragmented markets with different national preferences, different languages, and different regulatory regimes. American firms were able to gain economies of scale quickly, which allowed them to achieve positive network effects and to achieve economies of scale on development and operating expenses.

American firms entered first, and achieved network effects and economies of scale first simply because of first mover effects. The American firms were lucky enough to enter first, capture the market first, learn about consumer preferences first, and their advantage is a result of a lack of initiative among German companies when considering online opportunities.

American venture capital firms are more familiar with speculative ventures in information systems and have a more sophisticated attitude towards risk. German venture capital firms avoided losses, and most speculative ventures do fail. American firms managed their portfolios and were seeking $20 \mathrm{X}$ returns on a few winners. While German firms were avoiding losses and avoiding speculation, American firms were content to lose their investments $90 \%$ of the time, since if they achieved $20 \times 10 \%$ of the time they would still be doubling their money quickly.

American entrepreneurs and executives had different attitudes towards risk and towards public disapproval, and were willing to risk legal censure or public disapproval. German firms avoided anything that was not yet known to be legal and acceptable to the public. American firms risked anything that had not been shown to be illegal, or had not yet been successfully prosecuted as illegal. This is also supported by tables 1 and 2. American firms were also more willing to risk public disapproval. As Google CEO Eric Schmidt declared, his job was to understand what the public considered creepy, and to take Google as close to the creepy line as possible. "There is what I call the creepy line. The Google policy on a lot of things is to get right up to the creepy line and not cross it." [26]
American firms benefited from lax enforcement of privacy law in the US and lax enforcement of privacy law against US firms operating in Europe. While this was suggested by some executives late in their interviews, it did not receive nearly the degree of significance we anticipated when planning our studies.

American firms were able to implement platform envelopment strategies because of lax enforcement of antitrust law in the US and antimonopoly law in the EU or because of outdated antitrust law in the US and antimonopoly law in the EU. While this was acknowledged as potentially significant when we suggested it during our interviews, it was not volunteered or suggested by any interview subjects as a significant cause of the domination of the net by American platform operators.

\subsection{Is the American domination of the net significant in any way?}

Yes, because this domination represents domination by a few giant platform operators with near monopoly power in their respective spheres of influence. The fact that the firms are all American is not significant.

Yes, because this domination represents lost profits, which are earned by foreign firms and not EU firms. The repatriation of profits represents a significant drag on or tax on the economies of European nations.

Yes, because this domination represents lost employment opportunities within the EU. Almost all employment in internet giants is employment by American firms.

Yes, because the cost of paying for services from monopoly platform operators may be excessive. Google's charges for keywords is already a significant tax on commerce in the EU, and Amazon has the power to demand significant rebates from European firms that wish to sell to their consumers in their home market.

Yes, because American firms' lax attention to social norms allows fake news to prosper, which represents a threat to the functioning of democracy. Facebook's role in the manipulation of public opinion before the 2016 presidential election [1,25], and its manipulation of public opinion before the Brexit vote [30], are both significant examples.

Yes, because European firms will have fewer opportunities to expand in the future than their American counterparts. Future online applications will increasingly require integration into existing platforms, and European firms would systematically be denied access while applications developed by the platforms themselves would dominate. future ops

Yes, there are significant threats to the national security of all members of the EU. The one military office we spoke to said that the current situation was certainly grounds for concern. He argued that national security concerns existed any time key infrastructure, 
any key infrastructure, was operated entirely by foreign companies. He also believed that the risks were exacerbated as American culture and American interests appeared to be diverging rapidly from those of the EU.

No, Domination by a small number of American platforms does not matter at all. One interview subject said, in essence, the following. We are a global firm. We obey all the laws of all the countries in which we operate. Our competitors do as well. While we may face threats from competitors that understand the use of the net for customer support better than we do, we are not affected by Google, Facebook, Amazon, or other firms. We sell to giant industrial firms and to national governments; our customers do not search for sellers through Google, do not look on Facebook pages to make their purchasing decisions, and do not purchase on Amazon.

\subsection{Will American domination of the net be significant in the future?}

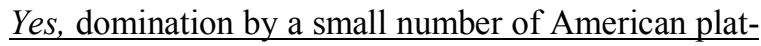
forms will become more significant in the future as a result of the increasing importance of the internet of things. More functions in the home will be integrated into platforms operated by American firms, especially Google Home and Amazon Alexa. These firms will exclude EU partners and will extend their own platform capabilities and their own domination.

Yes, EU retailers and manufacturers of small home appliances will have to pay significant fees to the American platforms for access to their own consumers. This is analogous to the high fees that some sellers today have to pay for positioning in search.

Yes, American operators of extensive platforms already have much more experience integrating functionality and managing complexity, and will provide better and more complete customer experience than any single EU firm or even any single EU industry. No individual European firm, and no single European industry, will be able to provide the level of functionality and the level of convenience offered by American platform operators.

Yes. As American platform operators gain power and their presence becomes more universal under the internet of things, national security concerns will become even more severe. American platform operators may be able to sabotage European homes, European roadways, and European manufacturing. This is exacerbated by trade wars and by the diverging cultural values of European and American societies.

No. German industry is already forging intra-industry alliances, such as the cooperation among automobile manufacturers. As a result, they will be able to provide smart car-to-car and car-to-road management, smart train-to-train and train to track and train to maintenance schedule management, and will be able to do so without need for any American intermediation.

\subsection{Impact of the New General Data Protection Regulation}

What impact will the new General Data Protection Regulation have on the balance between EU and American firms and how will it affect the power of currently dominant platform operators?

None. It is already too late for EU firms to recover their competitive position.

Positive. It will limit platforms' ability to commit privacy abuses in the future, which will level the playing field at least partially.

Positive. It will increase transparency, so users will be concerned if their data are abused. It will permit transportability, so users who are dissatisfied with the way their data are used on Facebook can, in theory, easily migrate along with their friends to a new competing website that provides a "cleaner" service.

Negative. EU firms will be held to even stricter standards while US platform operators will continue to ignore local regulations.

\section{Hypotheses}

We developed five hypotheses as a result of our interviews. We developed a sixth hypothesis when we planned how we might further explore whether the results of executives' beliefs, as expressed in surveys, were reflected in company performance, as reflected in econometric data.

We note that it would be bad research design to attempt to test six hypotheses with ten data points. However, in this paper we are not testing any hypotheses. We did generate our six hypotheses from conversations with only ten individuals, but these conversations averaged over an hour, and there was ample opportunity to explore a large number of topics. These topics were then reduced to six hypotheses.

We also note that all of our initial interviews were with German executives, and that our hypotheses all make statements about European executives. This is a serious limitation, which will be addressed in two ways in subsequent phases of the study. We will conduct interviews in other EU countries. And we conduct our surveys in enough EU countries to examine national differences in the responses we receive.

Hypothesis H1: European executives in all industries are aware of American domination of net-based businesses.

Hypothesis H2: European executives in all industries are concerned about American domination of netbased businesses.

Hypothesis H2A: European executives whose businesses require consumer interaction for retail sales are extremely concerned.

Hypothesis H2B: European executives whose busi- 
nesses require selling software to individuals are extremely concerned.

Hypothesis H2C: European executives whose businesses require distributing consumer-focused software through to individuals through online platforms are extremely concerned.

Hypothesis H2D: European executives whose businesses require selling cloud-based services to corporations are extremely concerned.

Hypothesis H2E: European military officers are extremely concerned.

Hypothesis $H 2 F$ : European executives whose businesses require intense interaction between their companies and their consumer products after sales are extremely concerned.

Hypothesis H3: European executives do not agree on the causes of American domination of net-based businesses.

Hypothesis H3A: Some European executives believe American domination is due to advantages resulting from selling into a single market.

Hypothesis $H 3 B$ : Some European executives believe American domination is due to first mover advantages. Hypothesis H3C: Some European executives believe American domination is due to a greater appetite for risk among venture capital and private equity firms.

Hypothesis H3D: Some European executives believe American domination is due to a greater willingness to skirt the limits of the law or the limits of enforcement of the law.

Hypothesis H3E: Some European executives believe American domination is due to lax enforcement of privacy laws, lax enforcement of antimonopoly law, gaps in monopoly law, or some combination of these factors.

Hypothesis H4: European executives do not agree on the future impact of the internet of things.

Hypothesis H4A: Some European executives believe that the internet of things will create new problems for manufacturers of products that require interaction between the company and their products after sale, because giant platforms are better positioned to control interactions with consumers.

Hypothesis H4B: Military officers believe that the internet of things will create new national security problems, due to the loss of control of critical infrastructure.

Hypothesis H4C: Some European executives believe that the internet of things will create no new problems for them, because their companies or their industries will be able to respond effectively.

Hypothesis H5: European executives do not agree on the way forward, or on the nature of appropriate responses to American domination of the net.

Hypothesis H5A: Some European executives believe that it is too late for any effective response.

Hypothesis H5B: Some European executives believe that better privacy regulation and better enforcement under the GDPR may help reduce the dominance of American platform operators.

Hypothesis H5C: Some European executives believe that the transparency and transportability control offered by the GDPR may help reduce the dominance of American platform operators.

Hypothesis H5D: Some European executives believe that clarification, modernization, and enforcement of antitrust law may help reduce the dominance of American platform operators.

Hypothesis H5E: Some European executives believe that cooperation within their industries may provide meaningful alternatives to existing platforms and thus may help reduce the dominance of American platform operators.

Hypothesis H6: The impact of American platform operators' domination of the net can be measured.

Hypothesis H6A: Traditional European chemical companies like AGFA and heavy industrial manufacturers like Siemens are performing at their traditional levels and have not yet been affected.

Hypothesis H6B: Traditional European service firms like Allianz and Deutsche Bank are performing at their traditional levels and have not yet been affected.

Hypothesis H6C: Traditional European retailers are starting to show the impact of competition from online sellers.

Hypothesis H6D: Software vendors like SAP are not affected in their traditional businesses but are unable to expand into areas like cloud services.

Hypothesis H6E: The EU equivalents of Giant pure internet companies like Google and Facebook are totally absent, and app developers are surviving only at the fringes and cannot compete successfully in critical areas like mapping or mail.

\section{Limitations of Our Current Research}

We see six limitations in our current research, all of which will be addressed in the subsequent stages of our research program.

- The first and most obvious limitation is the fact that all of our subjects were German executives. This would be a problem if executives in other major EU economies face a different set of problems.

- The second limitation is a result of the small size of our initial sample $[5,27]$. While a ten interviews may be enough to identify the set of critical issues, it is certainly not enough to identify their relative importance.

- Interviewer bias may be significant $[2,17]$. We have our own expectations about how the netbased economy works and about how platform industries operate. We may have unconsciously led or subjects in directions that we expected them to follow, or we may have unconsciously interpreted their comments in ways that supported our expectations.

- Recency bias may be significant $[10,16]$. The new 
General Data Protection Regulation had gone into effect days before our interviews and may had caused viewers to see privacy violations as a greater contributor to American domination than they would have previously. Alternatively, the implementation of the GDPR or may have led subjects to see the problem of privacy violation as more completely solved than they would have seen it before and thus as a less significant element in the domination of the net by American platform operators.

- Other, well-known effects may be significant, such as participant bias. Often in experiments where subjects are paid they seek to "to a good job" and they attempt to guess what the experimenters want to observe and then try to respond accordingly. That is not likely to be a factor here, but there is still a possibility that subjects may have attempted to cooperate and may have attempted to provide the answers we expected.

- Finally, while attitudinal studies will help us understand why certain effects may have occurred, they cannot demonstrate that they have indeed already occurred. Attitudinal studies complement econometric analyses, but they cannot substitute for econometric analyses.

\section{Future Research - Addressing The Limitations of Our Current Research.}

Our future research has three key elements. First we will conduct a additional interviews with executives in France, Britain, and Denmark, to learn if there are additional issues we should have included when constructing our hypotheses. Next, we will survey a broad executives in different positions, and in a wider range of industries, in Germany and elsewhere in the EU. We will also include government officials, industry associations, and military officers in our survey. This survey will specifically address our attitudinal hypotheses. We will determine if these executives believe that there is a problem with the domination of the net by American platform operators. We will determine, for those executives who do believe that there is a problem, what they believe the causes were.

Finally, we will conduct econometric analyses to determine where EU firms have demonstrably suffered adverse effects that could be explained by American domination of the net. Even if we can demonstrate harm we will not have established causality of course. But we will have demonstrated that there are economic effects that are consistent with the beliefs of European executives, and that are at least correlated with the effects of American domination of the net.

\section{Summary and Contributions}

We feel that the topic of control of online infrastructure is vitally important. As trade in services becomes more important, and as international trade disputes are increasing, it is important to understand the extent to which domination of the net by American platform operators does or does not affect the EU economy. We believe that our interviews have enabled us to create a set of testable hypotheses, which makes a modest contribution to our understanding of this phenomenon. While there is universal agreement among our interview subjects that the net is dominated by American operators of platforms, there was little consensus on causes, effects, or appropriate responses. Our survey will allow us to assess the perceived relative importance of different factors, as causes, as impacts, and as responses.

\section{References}

[1] Allcott, H., and Gentzkow, M. (2017). Social media and fake news in the 2016 election. Journal of Economic Perspectives, 31(2), 211-236.

[2] Bailar, B., Bailey, L., and Stevens, J. (1977). Measures of interviewer bias and variance. Journal of Marketing Research, 337-343.

[3] Benbasat, I., Goldstein, D. K., and Mead, M. (1987). The case research strategy in studies of information systems. MIS Quarterly, 11(3), 369386.

[4] Bittlingmayer, G., and Hazlett, T. W. (2000). DOS Kapital: Has antitrust action against Microsoft created value in the computer industry? Journal of Financial Economics, 55(3), 329-359.

[5] Button, K. S., Ioannidis, J. P., Mokrysz, C., Nosek, B. A., Flint, J., Robinson, E. S., and Munafò, M. R. (2013). Power failure: why small sample size undermines the reliability of neuroscience. Nature Reviews Neuroscience, 14(5), 365-376.

[6] Clemons, E. K., and Thatcher, M. E. (1998). Capital One: Exploiting an information-based strategy. Paper presented at the System Sciences, 1998., Proceedings of the Thirty-First Hawaii International Conference on.

[7] Clemons, E. K. and Thatcher, M. E. (2008). "Capital One Financial and a Decade of Experience with Newly Vulnerable Markets: Some Propositions Concerning the Competitive Advantage of New Entrants", Journal of Strategic Information Systems, Vol. 17, No. 3, Sept. 2008, pp. 179-189.

[8] Clemons, E. K., and Wilson, J. (2016). Selbstschutz ist nicht gleich Protektionismus. Retrieved from www.huffingtonpost.de/eric-kclemons/eu-datenschutz-rechtswidrigeunternehmenspraktiken b 8490876.html

[9] Dlouhy, J. A. (2018) "Trump's Coal Gambit May Yield Political Points But Not Mining Jobs", Bloomberg, June 14, 2018, www.bloomberg.com/news/articles/2018-0614/trump-s-coal-gambit-may-yield-politicalpoints-not-mining-jobs.

[10] Eagle, N., Pentland, A. S., and Lazer, D. (2009). 
Inferring friendship network structure by using mobile phone data. Proceedings of the national academy of sciences, 106(36), 15274-15278.

[11]Edelman, B. (2015). Does Google leverage market power through tying and bundling? Journal of Competition Law and Economics, 11(2), 365-400.

[12]Edelman, B., and Geradin, D. (2016). Android and competition law: exploring and assessing Google's practices in mobile. European Competition Journal, 12(2-3), 159-194.

[13] Eisenhardt, K. M. (1989). Building theories from case study research. Academy of management review, 14(4), 532-550.

[14]Eisenmann, T., Parker, G., and Van Alstyne, M. W. (2006). Strategies for two-sided markets. Harvard business review, 84(10), 92.

[15] Granados, N. F., Kauffman, R. J., and King, B. (2008). How has electronic travel distribution been transformed? A test of the theory of newly vulnerable markets. Journal of Management Information Systems, 25(2), 73-96.

[16] Hallowell, M. R., and Gambatese, J. A. (2010). Qualitative research: Application of the Delphi method to CEM research. Journal of construction engineering and management, 136(1), 99-107.

[17] Hildum, D. C., and Brown, R. W. (1956). Verbal reinforcement and interviewer bias. The Journal of Abnormal and Social Psychology, 53(1), 108111.

[18] Jick, T. D. (1979). Mixing qualitative and quantitative methods: Triangulation in action. Administrative science quarterly, 24(4), 602-611.

[19] Lambert, N. A. (1995). Admiral Sir John Fisher and the concept of flotilla defence, 1904-1909. The Journal of Military History, 59(4), 639-660.

[20]Lee, A. S. (1989). "A Scientific Method for MIS Case Studies", MIS Quarterly, March 1989, pp. 33-49.

[21] Lundberg, C. C. (1976). Hypothesis creation in organizational behavior research. Academy of management review, 1(2), 5-12.

[22] Lykken, D. T. (1968). Statistical significance in psychological research. Psychological bulletin, 70(3p1), 151-159.

[23] Parker, G. G., and Van Alstyne, M. W. (2005). Two-sided network effects: A theory of information product design. Management science, 51(10), 1494-1504.

[24] Parker, G. and Van Alsyne, M. (2016) Platform Revolution: How Networked Markets Are Transforming the Economy - and How to Make Them Work for You, W. W. Norton \& Company, pp. 352.

[25] Rainie, H., Anderson, J. Q., and Albright, J. (2017). The future of free speech, trolls, anonymity and fake news online: Pew Research Center Washington, DC.

[26] Saint, N. (2010). Eric Schmidt: Google's Policy Is
To "Get Right Up To The Creepy Line And Not Cross It". Retrieved from www.businessinsider.com/eric-schmidt-googlespolicy-is-to-get-right-up-to-the-creepy-line-andnot-cross-it-2010-10? IR=T

[27] Sandelowski, M. (1995). Sample size in qualitative research. Research in nursing and health, 18(2), 179-183.

[28] Satariano, A. and Nicas, J. "E.U. Fines Google \$5.1 Billion in Android Antitrust Case", The New York Times, July 18, 2018, www.nytimes.com/2018/07/18/technology/googl e-eu-android-fine.html.

[29] Sayer, P. (2018). "Android and antitrust: The EU's Google case explained", ComputerWorld, June 7, 2018,

www.computerworld.com/article/3279954/mobil e-wireless/android-and-antitrust-the-eus-googlecase-explained.html.

[30] Speed, E., and Mannion, R. (2017). The rise of post-truth populism in pluralist liberal democracies: challenges for health policy. International journal of health policy and management, 6(5), 249-251.

[31] Swanson, A. "White House to Impose Metal Tariffs on E.U., Canada and Mexico", The New York Times, www.nytimes.com/2018/05/31/us/politics/trumpaluminum-steel-tariffs.html.

[32] The Local. (2017). German corporations team up against US tech heavyweights with new platform. Retrieved from www.thelocal.de/20170828/germancorporations-team-up-against-us-techheavyweights-with-new-platform.

[33] U.S. Department of Justice. (1998). Complaint : U.S. v. Microsoft Corp. Retrieved from www.justice.gov/atr/complaint-us-v-microsoftcorp.

[34] Wu, T. (2010). The Master Switch: The Rise and Fall of Information, Knopf pp. 384.

\section{Appendix A - Sources for Reports on Incidents of Privacy Violations}

1. Barrett, Brian. "Spotify clears up its controversial privacy policy." Wired. 2015, www.wired.com/2015/08/spotify-clears-up-itsprivacy-policy/"

2. Belgium probes Google's Street View." AFP. 2011, phys.org/news/2011-04-belgium-probesgoogle-street-view.html.

3. Conner, Cheryl. "Your privacy has gone to the [Angry] Birds." Forbes. 2012, www.forbes.com/sites/cherylsnappconner/2012/12/05/your-privacy-has-gone-to-the-angrybirds/\#2ed9997a39b6.

4. "Consumer watchdog asks FTC to act against Google Home; Amazon Echo digital assistants for 
Deception, COPPA violation." Consumer Watchdog. 2017, www.prnewswire.com/news-releases/consumer-watchdog-asks-ftc-to-actagainst-google-home-amazon-echo-digital-assistants-for-deception-coppa-violation300573395.html.

5. Crosman, Penny. "Large U.S. banks scramble to meet EU data privacy rules." American Banker. 2018, www.americanbanker.com/news/large-usbanks-scramble-to-meet-eu-data-privacy-rules.

6. Deahl, Dani. "Seattle says Facebook has violated its political ad transparency law." The Verge. 2018, www.theverge.com/2018/2/7/16988030/seattle-facebook-violated-political-ad-transparencylaw.

7. Eddy, Melissa and Scott, Mark. "Delete hate speech or pay up, Germany tells social media companies." The New York Times. 2017, www.nytimes.com/2017/06/30/business/germany-facebook-google-twitter.html.

8. Enright, Allison. "Privacy suit takes aim at Amazon." Digital Commerce 360. 2011, www.digitalcommerce360.com/2011/03/04/privacy-suittakes-aim-amazon/.

9. "EU court backs 'right to be forgotten' in Google case." BBC. 2014, www.bbc.com/news/world-europe-27388289.

10. "EU Directive 95/46/EC - The Data Protection Directive." Data Protection Commission, www.dataprotection.ie/docs/EU-Directive-95-46EC-Chapter-1/92.htm.

11. Fair, Lesley. "FTC settlement with Amazon yields $\$ 70$ million for consumers, advice for business." Federal Trade Commission. 2017, www.ftc.gov/news-events/blogs/businessblog/2017/05/ftc-settlement-amazon-yields-70million-consumers-advice.

12. Farivar, Cyrus. "Czech Republic stops Google from further Street View photography." Reuters. 2010, www.dw.com/en/czech-republic-stopsgoogle-from-further-street-view-photography/a6006085 .

13. Federal Data Protection Act. German Law Archive. 2017, germanlawarchive.iuscomp.org/? $p=712$.

14. Fioretti, Julia. "EU court rejects Facebook class action suit by privacy activist." Reuters. 2018, www.reuters.com/article/us-eu-court-facebookprivacy/eu-court-rejects-facebook-class-actionsuit-by-privacy-activist-idUSKBN1FD33U.

15. Gijzemijter, Martin. "Privacy outrage causes bank to ditch plans for targeted ads based on customers' spending habits." ZDNet. 2014, www.zdnet.com/article/privacy-outrage-causesbank-to-ditch-plans-for-targeted-ads-based-oncustomers-spending-habits/.

16. Goodin, Dan. "Researchers find 256 iOS apps that collect users' personal info." Ars Technica. 2015, arstechnica.com/information-technology/2015/10/researchers-find-256-ios-apps-thatcollect-users-personal-info/.

17. "Google bosses convicted in Italy." BBC, 2010, news.bbc.co.uk/2/hi/technology/8533695.stm.

18. "Google faces $\$ 18$ million fine for web privacy violations: Dutch watchdog." Reuters, 2014, www.reuters.com/article/us-privacy-googledutch/google-faces-18-million-fine-for-web-privacy-violations-dutch-watchdog-idUSKBN0JT1TG20141215.

19. "Google loses UK appeal court battle over 'clandestine' tracking." The Guardian. 2015, www.theguardian.com/technology/2015/mar/27/google-loses-uk-appeal-courtbattle-clandestine-tracking.

20. Granville, Kevin. "Facebook and Cambridge Analytica: What you need to know as fallout widens." The New York Times. 2018, www.nytimes.com/2018/03/19/technology/facebook-cambridge-analytica-explained.html.

21. Greenwald, Glenn et al. "Microsoft handed the NSA access to encrypted messages." The Guardian. 2013, www.theguardian.com/world/2013/jul/11/microsoft-nsa-collaboration-user-data.

22. Hattem, Julian. "Verizon to pay $\$ 7 \mathrm{M}$ over privacy violations." The Hill. 2014, thehill.com/policy/technology/216514-verizon-to-pay-7-millionover-privacy-violation.

23. Hern, Alex. "Uber broke Apple's iOS privacy rules and Tim Cook wasn't happy about it." The Guardian, 2017, www.theguardian.com/technology/2017/apr/24/uber-broke-apple-ios-privacyrules-tim-cook-travis-kalanick.

24. Jolly, Ieuan. "Data protection in the United States: Overview." Thomson Reuters Practical Law. 2017, $\quad$ content.next.westlaw.com/Document/I02064fbd1cb611e38578f7ccc38dcbee/Vie w/FullText.html? contextData $=($ sc. Default $) \&$ transitionType $=$ Default\&firstPage $=$ true \&bhcp $=1$.

25. Kang. Y. Peter. "HSBC to pay $\$ 13 \mathrm{M}$ to end privacy row over recorded calls." Law360. 2016, www.law360.com/articles/833597/hsbc-to-pay$13 \mathrm{~m}$-to-end-privacy-row-over-recorded-calls.

26. Kiss, Jemima. "Google admits collecting Wi-Fi data through Street View cars." The Guardian. 2010, $\quad$ www.theguardian.com/technology/2010/may/15/google-admits-storing-privatedata.

27. Koh, Yoree. "Twitter hit with suit claiming it snoops on direct messages." The Wall Street Journal. 2015. www.business-humanrights.org/en/usausers-sue-twitter-for-violating-privacy-laws-byallegedly-intercepting-reading-direct-messages\#c127922.

28. Lee, Dave. "Lyft investigates privacy abuse claim." BBC. 2018. www.bbc.com/news/technology-42827636. 
29. Lomas, Natasha. "Facebook fined \$122M in Europe over misleading WhatsApp filing." TechCrunch, 2017. techcrunch.com/2017/05/18/facebook-fined$122 \mathrm{~m}$-in-europe-over-misleading-whatsapp-filing/.

30. Lomas, Natasha. "Facebook fined $€ 1.2 \mathrm{M}$ for privacy violations in Spain." TechCrunch. 2017, techcrunch.com/2017/09/11/facebook-fined-e12m-for-privacy-violations-in-spain/.

31. Lomas, Natasha. "Uber agrees to 20 years of privacy audits to settle FTC data mishandling probe." TechCrunch.

2017 , techcrunch.com/2017/08/15/uber-agrees-to-20years-of-privacy-audits-to-settle-ftc-data-mishandling-probe/.

32. McLernon, Sean. "Santander unit accused of secretly recording phone calls." Law360. 2013, www.law360.com/articles/416198/santander-unitaccused-of-secretly-recording-phone-calls.

33. Moody, Glyn. "Detailed medical records of 61 million Italian citizens to be given to IBM for its "cognitive computing" system Watson." Privacy News Online. 2017, www.privateinternetaccess.com/blog/2017/05/detailed-medical-records61-million-italian-citizens.

34. O'Connor, Nuala. "Reforming the U.S. approach to data protection and privacy." Council on Foreign Relations. 2018, www.cfr.org/report/reforming-us-approach-data-protection.

35. Ozer, Nicole. "Note to self: Siri not just working for me, working full-time for Apple, too." ACLU. 2012, www.aclu.org/blog/national-security/noteself-siri-not-just-working-me-working-full-timeapple-too.

36. "Prime example of privacy violation? Amazon wristband." Liquid Litigation Management, Inc. 2018, www.liquidlitigation.com/blog/prime-example-privacy-violation-amazon-wristband/.

37. Quain, John. "Changes to OnStar's privacy terms rile some users." The New York Times. 2011, wheels.blogs.nytimes.com/2011/09/22/changesto-onstars-privacy-terms-rile-some-users/.

38. Rach, Claudia. "Google may drop Street View in EU if photo storage time is cut." Bloomberg Businessweek. 2010.2 web.archive.org/web/20101121041217/http://www.businessweek.com/news/2010-03-03/google-maydrop-street-view-in-eu-if-photo-storage-time-iscut.html.

39. Reardon, Marguerite. "Verizon racks up $\$ 1.35 \mathrm{M}$ fine for violating consumer privacy." CNET. 2016, www.cnet.com/news/verizon-racks-up-1-35-mbill-for-violating-consumer-privacy/.

40. Ruiz, Rebecca. "F.C.C. fines AT\&T \$25 million for privacy breach." The New York Times. 2015, bits.blogs.nytimes.com/2015/04/08/f-c-c-finesatt-25-million-for-privacy-breach/.

41. Scott, Mark. "Facebook gets slap on the wrist from 2 European privacy regulators." The New York Times. 2017, www.nytimes.com/2017/05/16/technology/facebook-privacy-france-netherlands.html.

42. "Shazam is always listening to everything you're doing." New York Post. 2016, nypost.com/2016/11/15/shazam-is-always-listeningto-everything-youre-doing/.

43. Singel, Ryan. "Foursquare puts money before privacy." Wired. 2010, www.wired.com/2010/06/foursquare-privacyfunding/.

44. Streitfeld, David. "Google concedes that drive-by prying violated privacy." The New York Times. 2013, www.nytimes.com/2013/03/13/technology/google-pays-fine-over-street-view-privacybreach.html.

45. "Telefonica planning to sell anonymized customer data." Handelsblatt. 2017, global.handelsblatt.com/companies/telefonica-exposed-for-selling-customer-data-711974.

46. Toor, Amar. "Facebook is still violating user privacy, Dutch and French regulators say." The Verge. 2017, www.theverge.com/2017/5/17/15651740/facebook-privacyviolation-france-netherlands-fine.

47. Treanor, Jill. "Tesco Bank cyber-thieves stole $£ 2.5 \mathrm{~m}$ from 9,000 people." The Guardian. 2016, www.theguardian.com/business/2016/nov/08/tesco-bank-cyber-thieves-25m.

48. Wouters, Jorgen. "Disney-owned company fined \$3 million for children's privacy violations." AOL.com, 2011. www.aol.com/2011/05/13/disney-owned-company-fined-3-million-for-childrens-privacy-vio/.

49. Zeldin, Wendy. "Switzerland: Court decision in privacy violation case partially favorable to Google." The Law Library of Congress. 2012, www.loc.gov/law/foreign-news/article/switzerland-court-decision-in-privacy-violation-case-partially-favorable-to-google/.

\begin{tabular}{|c|c|c|c|c|c|c|}
\hline $\begin{array}{c}\text { Location of } \\
\text { Firm }\end{array}$ & \multicolumn{2}{|c|}{ Incidents Reported } & \multicolumn{2}{c|}{ Formal Complaints } & \multicolumn{2}{c|}{ Penalty Imposed } \\
\cline { 2 - 7 } & In US & In EU & In US & In EU & In US & In EU \\
\hline US & 21 & 19 & 10 & 17 & 8 & 13 \\
\hline EU & 6 & 3 & 1 & 0 & 1 & 0 \\
\hline
\end{tabular}

Table 1.-Analysis of incidents of privacy violation, formal legal and regulatory complaints, and punishments, comparing US and EU firms from 2010 through 2018. 